\title{
Comparing Preaching in Acts and Contemporary Preaching in Kumasi-Ghana.
}

\author{
Godfred Baffour-Awuah1 (iD , Jonathan E.T. Kuwornu-Adjaottor ${ }^{\text {(D) }}$ \& Patrick Yankyera ${ }^{2}$ \\ 1 Department of Theology, Christian Service University College -Kumasi Ghana. \\ 2 Department of Religious Studies, Kwame Nkrumah University of Science and Technology (KNUST), Kumasi, Ghana.
}

\begin{abstract}
Kumasi is saturated with preachers preaching all manner of messages. The media space, along major streets, the church space, as well as the market centres have all witnessed an insurgence of many different preachers. The preaching of the Gospel occupies a major place in the Christian church. Both Jesus and the Apostles as revealed in scripture made preaching and teaching an important part of their ministries. This paper examines the nature of Christian preaching in contemporary times in the city of Kumasi, Ghana. The nature of contemporary preaching is compared to that of preaching in the Book of Acts. Qualitative data was gathered through the preacher's visits to six churches; sixty listeners and 22 preachers were interviewed in Kumasi. One of the major findings was that some preachers in the city of Kumasi today have turned the preaching of the gospel into a business venture. This study advocates the urgent need to guide preaching in the world today with a biblical motif. Sound biblical preaching is significant for the advancement of the Christian faith. It recommends that preaching must result in societal transformation so contemporary preachers must prioritize relating sermons that shoot down the growing ills in the Ghanaian society. The study adds to knowledge in biblical preaching and brings to bear how useful the guiding mirror of scripture could protect contemporary Christian ministry from destructive messages.
\end{abstract}

Keywords: Contemporary Preaching, Book of Acts, Christian Ministry.

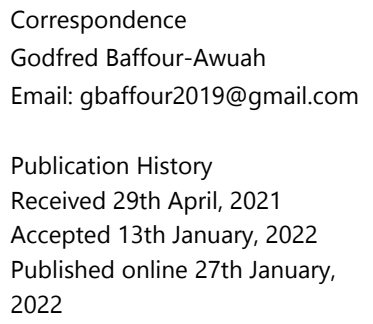

\section{INTRODUCTION}

Ghanaian hospitality extends to preachers passionately to the point that society accommodates all kinds of preachers and their messages. This has necessitated the proliferation and patronage of preachers and the multidimensional facet of preaching messages in Kumasi, Ashanti Region, Ghana. Chapter 3 of Matthew's gospel records the emergence of John the Baptist and then followed by his preaching of repentance. In Luke 4:18-19, Jesus came down from the wilderness to announce to the whole community that He has been anointed to preach the gospel to the poor. Apostle Paul said, "woe is me if I preach not the Gospel" (1 Cor. 9:16KJV). According to John Stott, preaching is central and distinctive to Christianity and has been recognized throughout the Church's long and colourful story from the beginning. ${ }^{1}$ It can be noted that the apostles after the day of Pentecost gave priority to the ministry of preaching as indicated in Acts 6 . They turned down all requests to get involved in other forms of service, in order to be devoted to the ministry of 1 John R.W. Stott, I believe in Preaching (London: Hodder and Stoughton, 1982), 16. 
prayer and the preaching of the word (v.4). ${ }^{2}$ Jesus commands all and sundry in the Christian fraternity to go into the whole world and preach the Good News to every creature (Mk 16:15-17).

Since the place of preaching is highly esteemed in scripture and the Christian community, it is significant to subject preaching in today's Christianity to proper scrutiny. Stott is emphatic when he states that Christianity is in its very essence, a religion of the Word of God. ${ }^{3}$ The responsibility of preachers in the Christian realm is overwhelmingly significant and it goes farther into the full fabric of society as a balm that heals difficult conditions.

Translated into the practice of leadership, the life and teaching of Jesus present a pattern for Christian leaders to feed, care for, and look after the sheep of Jesus. ${ }^{4}$ What this means is that they are to feed people with the right food, by preaching and teaching the undiluted Word of God. There is the need to have a critical look at the preaching phenomenon and how or who it is modelled after. Bediako observes that the world exalts efficiency and control - has no models to offer to those who desire to be shepherds in the way Jesus was as a shepherd. ${ }^{5}$ Bediako further observes a widespread sense among African Christians that the church is in crisis and the problem has to do with leadership. ${ }^{6}$ As far as the church is concerned the preacher is often identified with the main leadership. If the preacher is perceived to be the main source of any crisis in the church, then this affects the delivery of the Word of God. If such a situation persists in the Ghanaian society and in the Christian community specifically then it becomes imperative to examine the nature of preaching in contemporary times in order to ascertain how it deviates or conforms to Christian theology. The Gospels, the book of Acts, the Epistles as well as the Book of Revelation, all provide examples and exhortations to preach the truth in fulfilment of God's will. ${ }^{7}$ Consequently, this paper compares Christian preaching in presentday Kumasi to the preaching of the early apostles as recorded in the book of Acts. It answers the question, what is the nature of Christian preaching in Kumasi? It discusses among other issues the nature of Christian preaching, preaching in the Book of Acts, the modern day trend of preaching in Kumasi, and the implications of Christian preaching in the Ghanaian society.

\section{Preaching Defined}

Stepping into the main issues requires a well-defined and comprehensive portrait of what preaching represents. The Wiersbes define preaching as the communication of God's truth by God's servants to meet the needs of people. ${ }^{8}$ Their definition brings out three vital steps; first, the truth from the Word of God must be well presented to people. Secondly, this activity must be handled by persons who have submitted themselves to the Scriptures to earn the status of servants of God. Lastly, unlike the popular perception where some preachers approach their tasks only to satisfy themselves, here, it is to respond to the needs of the audience. Haddon Robinson posits that God himself speaks through the personality and message of a preacher to confront men and women in order to bring them to himself. ${ }^{9}$ Preaching is also a divine message carried through the vehicle of the messenger's personal character and words to encourage people to submit to their maker.

This means that the essential nature of preaching is all about God communicating to humans via first, the personality of a herald. Thus, the totality of the person serving as the carrier of the Word forms part of the preaching, and one is not isolated from the message he or she ministers to people. Stott also underscores this view by emphasising two major elements that are non-negotiable in this all-important exercise to communicate God's mind to mankind. According to Stott, preaching is the communication of truth by man to men, by way of two essential elements, that is, truth and personality, preaching is thus bringing out the

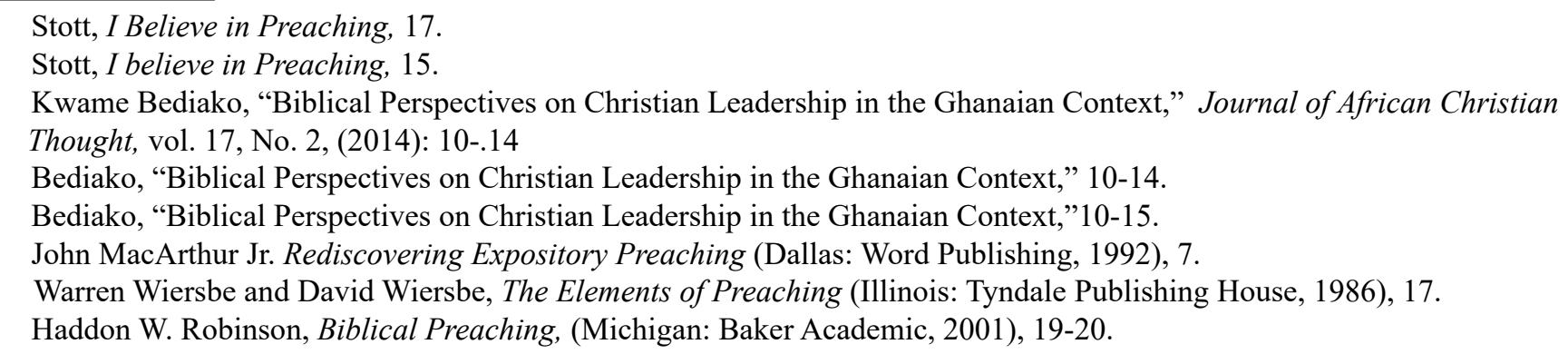


truth through human personality. ${ }^{10}$ It is important to note that a negative personality could affect the act of preaching greatly as inferred in this view. Moreover, it also reveals that through the preaching of the Word, God is in the process of arresting and compelling humankind to himself.

In another sense, preaching is considered as a means of approaching individuals with what they are not conversant with especially concerning the works of God that lead to salvation. In the view of Bowen preaching means bringing a new message, kerygma or proclaiming the euangelion (good news) of what God has done, often to people who have not heard it before. ${ }^{11}$ It is the attempt to introduce a new life concept from the Good News to an audience or community that is new to this concept of new life or worldview. Information determines what forms a people's mentality and picture about this life. So when rays of the gospel succeed in flashing through their mind, a new world view could be created.

The act of preaching plays a strong and effective role with respect to spreading the redemptive message of Christ. Per Olford's definition, preaching is God's ordained means of communicating His redeeming truth. ${ }^{12}$ The preaching of the gospel leads those who embrace the good news and the Lordship of Jesus Christ out of the slavery of the flesh and the bondage of sin into the community of the redeemed. Many are ignorant of this wonderful story of redemption and need to know about it because it is only the gospel that releases the power that saves the sinner (Rom 1:16). God in his infinite mercy has made it possible by consecrating the act of preaching through men as the vehicle to bring this light of redemption to the world.

\section{Types of Preaching Messages}

The art of preaching can be seen in many forms, but this study discusses briefly some of the major ones. All discussions regarding preaching tend to divide it into three main types: the topic or subject, text and exposition. MacArthur Jr. observes that topical messages usually combine a series of biblical texts or passages that generally serve as a gateway into whatever subject the preacher chooses to address. ${ }^{13}$ According to him, the topical or the textual methods do not convey a serious effort to interpret, understand, explain, or apply God's truth in the context of the Scripture(s) used. However, in contrast, expository preaching tends to focus predominantly on the selected text(s) along with its context. ${ }^{14}$ This has been considered by many scholars and students of preaching as the most effective method of preaching. Koesler affirms that biblical exposition is a good way to teach theology in context. ${ }^{15}$ Surely, it is an important approach to the work of preaching in a fashion that could expose the hidden truths in a text to enlighten people to deepen their knowledge about God.

The character of this perceived ideal way of communicating the heart of God to people is seen in how expository preaching relies on the authority of God's Word. Preaching that is considered as effective and powerful involves the intentional commitment of the preacher to connect the "head and the heart" to the central message of the text in such a way that the hearer can understand fully what the passage is saying about the message of the text, as it communicates the appropriate ways that can help listeners to implement the proclamation or message relevantly to their lives. ${ }^{16}$ It is a method of preaching or teaching which simply suggests that the text or the biblical passage will always do the talking but the preacher's task is to help the congregation digest into their unique situations. All well-meaning preachers of today could embrace it to enrich their style of delivery to feed their audiences with the right message.

\section{METHODOLOGY}

In the quest to answer the research question, the author went around, sampled six selected churches in Kumasi from six different denominations and also participated in their worship services, whilst taking note of the contents of their messages. Also, tapes and radio recordings of messages of the preachers were

10 Stott, I Believe in Preaching, 265-266.

11 Roger Bowen eds, A guide to Preaching, (London: SPCK, 2005), 41.

12 Stephen F. Olford and David L. Olford, Anointed Expository Preaching, (Nashville: B\&H Publishing Group, 1998 ), 229.

13 MacArthur, Jr. Rediscovering Expository Preaching, 9.

14 MacArthur, Jr. Rediscovering Expository Preaching, 9.

15 John Koesler, The Moody Handbook of Preaching, (Chicago: Moody Publishers, 2008), 30-71.

16 Koesler, The Moody Handbook of Preaching, 30-71. 
analyzed. Qualitative data gathered through eighteen selected preachers in Kumasi including three itinerant preachers and ten regular listeners from each denominational group were used to assess how denominational perspective affects preaching. In all, three preachers each from denominational groupings -Mainline Churches, Pentecostal Stream, Neo-Pentecostals, Neo-Prophetic, African Independent Churches (AICs) and the Self-Styled itinerant Evangelists or Public preachers were included in the study. Among these groups, two preachers were interviewed and one was selected for the message-content analysis. In effect, those selected for content analysis were not interviewed but ten of their listeners were interviewed. In all, sixty listeners and twenty-two preachers were interviewed including ten experienced ministers in the city.

\section{Preaching in the Book of Acts}

The Book of Acts can be summarized in a single phrase as "the triumph of the gospel" because it is a triumphant story of how the early church in the power of the Holy Spirit saturated the then known world with the message of God's salvation in Christ Jesus. ${ }^{17}$ According to Williams, Acts is the only authentic record of the first years of the church's history. It is known among scholars of the New Testament (N.T) that whoever wrote the third Gospel was also considered as the writer of the book of Acts; who traditionally has been identified with Luke a physician and companion of Paul. ${ }^{18}$ Luke's authorship of the book of Acts is favoured by the internal evidence of the book that indicates some passages in the first person plural, and the plausible interpretation of them is that they came from the pen of one of Paul's companions. ${ }^{19}$ Another clear evidence from external sources is that of Irenaeus who names Luke as the writer of Acts. ${ }^{20}$ No one knows the actual place of writing of the Book of Acts, though many have suggested locations such as Rome, Caesarea, Antioch, Ephesus and Corinth. Even if all the writers who have attempted to date the book, have overstated their case, a date for Acts around AD 75 seems most likely. It is significant to note that the book of Acts ends at chapter 28:31, but the story of Jesus' life and ministry goes on wherever his Spirit finds men and women ready to believe, obey, give, suffer, and, if need be, die for him. ${ }^{21}$ Criswell argues that the story constitutes a journey of 34 years from $\mathrm{AD} 30$ to AD 64, and ends with a hero in prison. ${ }^{22}$ Moreover, AD 70-75 seems more reasonable.

\section{The Nature of Preaching in the Book of Acts}

A look at the nature of Christian preaching in the book of Acts is significant to this study as it serves as a framework for comparison with the current direction of preaching in Kumasi. First, preaching in Acts is characterized by a biblical appeal. On the day of Pentecost, Peter preached from Old Testament (O.T.) texts including the Psalms and Joel (Acts 2:14-35). According to Gaebelein, Peter in his message explains the strange happenings among the early church at Pentecost as being the fulfilment of the prophecy in Joel 2:2832; and further quotes Psalm 16 and Psalm 110 to support his submission concerning Jesus. ${ }^{23}$ He further opines that the usage of Joel is very important for an appreciation of exegetical practice and commitment to sound biblical teaching that should serve as an example for contemporary preaching. ${ }^{24}$ This shows clearly that the preachers in Acts were people of the Bible. Again, the apostle Peter quoted the O.T. when he reminded the Jews of their manhandling of Jesus as an act of ignorance already predicted in scripture and went all the way to quote Moses' prophecy concerning Jesus, and that of the Prophets (Acts 3:17-26). Harrison affirms that Peter selected his text from Numbers 15:32-36 and was calling the attention of the Jews to the fact that

17 Chad Brand etal. Eds. Holman Illustrated Bible Dictionary, (Nashville: Holman Bible Publishers, 1998$), 24$.

18 David J. Williams, Acts, (Michigan: Baker Books, 1990), 1-2.

19 Ian Howard Marshall, The Acts of the Apostles: An Introduction and Commentary, (Michigan: Wm. B. Eerdmans Publishing Company, 1982), 44.

20 Marshall, The Acts of the Apostles: An Introduction and Commentary, 6.

21 Williams, Acts, 17.

22 Wallie. A. Criswell, Acts: An Exposition, Volume I Chapters 1-8, (Michigan: Zondervan Publishing House, 1978$), 17$.

23 Frank E. Gaebelein ed. The Expositor's Bible Commentary, Michigan: Grand Rapids (Zondervan Corporation, 1981) 275279.

24 Gaebelein ed. The Expositor's Bible Commentary, 275. 
the prophets had made it known that God was sending them a Messiah. ${ }^{25}$ Similarly, Stephen in Acts 7 narrated the history of God's dealings with Israel covered in the Pentateuch and connected it to their realization in Christ. Pauline teachings in the book of Acts were also built on scripture to establish the counsel of God and not his own ideas or that of men (Acts 13:32-41). There are many references from the O.T. cited by the preachers in Acts to give a strong biblical emphasis of their preaching and teaching since that was the only inspired scripture available.

On the other hand, contextualization was also well adopted by the preachers in the Book of Acts in their message delivery. Clearly speaking, the preaching in Acts took consideration of the audience. In Acts 3:13 Peter uses the expressions, the God of Abraham, Isaac and Jacob; and "the God of our fathers". This demonstrates his knowledge about his audience identified as Jews and addressed them in a language they will easily grasp or catch their attention. Paul's engagement with his audience in Athens who worshipped the 'unknown god' is another explicit display of contextual prowess in the art of preaching. His Greek audience worshipped an unknown god so he also presented to them the 'unknown God' which finally landed on the 'known Jesus' (Acts 17:22-25). This suggests that the preachers took their time to know the environment of their audience and perhaps their cosmology and delivered their sermons meaningfully in that context. Boice reveals that the apostle Paul was very observant, as he walked through the city of the Greeks he noticed an inscription 'To an Unknown God' and volunteered to teach them about him (Acts 17:23). ${ }^{26}$

Furthermore, the central message preached in Acts was all about Jesus and not the exploits of men or the apostles. The theological emphasis of preaching comes to play when Peter told his audience that 'this Jesus' is the one prophet Moses ordered his congregation to expect his coming and adhere to; and on many occasions, the apostle told them that Jesus is the one God attested to them with great power (Acts 3:13;2:22). Again, Paul was accused of preaching Jesus and the resurrection in Acts 17:18. Luke reports that Philip went down to Samaria to 'proclaim Christ' (Acts 8:5). Thus their message was all about Jesus of Nazareth all the way. Stott remarks that the excellent feature of Peter's preaching; is its Christ-centeredness which directs his audience attention from him to Christ. ${ }^{27}$

Moreover, preachers in the book of Acts had an intrinsic motivation, an inner desire to see their audience repent. On many occasions, they invited their listeners to repent of their sins (Acts 2:38; 3:19; 8:22: $17: 30 ; 26: 19-20)$. Marshal sees Peter's response "repent" in Acts 2:38 as a call on Christian preachers to treat it as a major requirement in preaching. ${ }^{28}$ This position elucidates the fact that the early Christian preachers were not materialistic and did not concentrate on the financial or material benefits they would derive out of preaching. In fact, exploitation had no place in their sermons and actions but rather a desire of people to turn away from sin towards God. Green further evaluates Paul's preparedness to work to feed himself and that of his friends, and his saying that he coveted no one's gold or apparel or silver (Acts 20:33-34). ${ }^{29}$ This constitutes an attitude of selflessness which is very significant for the Christian preacher.

\section{The Impact of Preaching in the Book of Acts}

It is vital and very essential to also study the outcome of the preaching in Acts to find out what it achieved. There is no doubt that it resulted in the salvation of thousands of their hearers (Acts 2:40-41; 4:4; an entire household 16:31-33; even politicians were saved 13:12). Gaebelein reveals that baptism was seen by the Jews as a ritual to convert Gentiles into Judaism but upon hearing the sermon of Peter on the day of Pentecost about 3000 were converted and took a revolutionary step to be baptized. ${ }^{30}$

Another significant impact of their preaching revealed in Acts is the unity and love among believers (Acts 2:44). The messages of the apostles in the early church reportedly ignited unity and charity among them towards one another to the point that none of them lacked anything. Stott postulates that modern day

\footnotetext{
25 Everett F. Harrison, Interpreting Acts: The Expanding Church, Michigan:(Grand Rapids (Academic Books, 1986$) 84$.

26 James Montgomery Boice, Acts: An Expositional Commentary, (Grand Rapids, Baker Books, 1997$) 297$.

27 John R.W. Stott, The Message of Acts, England (Inter-Varsity Press, 1990) 92.

28 Ian Howard Marshall, The Acts of the Apostles, Michigan (Wm. B. Eerdman's Publishing Company, 1980) 80.

29 Green, Acts for Today, 154

30 Gaebelein ed. The Expositor's Bible Commentary, 286.
} 
believers can also devote themselves to the apostles teaching by submitting fully to the New Testament texts and also replicating their lifestyle thereby experiencing what they experienced. ${ }^{31}$

\section{The Nature of Christian Preaching in Kumasi}

There were several findings concerning the activities of preachers in the Kumasi metropolis. Many revelations also surfaced from the content of some messages sampled from the author's visits and observation, and data gathered through interviews. Christianity in Kumasi has over the years been characterised by church activities including Sunday worship services, church retreats and revival programmes, mid-week teaching services and prayer meetings among others. In all these activities, it was observed that messages were preached to the audience. Again, some itinerant preachers often place themselves in busy areas especially the central business District of Kumasi (CBD) including Adum, Kejetia, Asafo, among others. The field study was to examine the nature and impact of the preaching that goes on at all these areas for a proper comparison with the preaching in the Book of Acts, to be done.

It was established that the nature of some of the messages in Kumasi was found to be often distorted. A minister of the gospel opined that the established churches have a doctrine to follow but the independent churches are always tempted to preach anything to attract people to their auditoriums and they end up distorting the Scriptures. ${ }^{32}$ One itinerant preacher added that perverted gospel is easily identified in the city among various preaching messages because the Word of God has been sidelined and substituted with a different gospel which talks about the preacher's trips abroad but refuses to correct the listeners from the rising trend of indecent dressing. ${ }^{33}$ It was also revealed that many preaching messages focus mainly on giving directions to seekers about where the preacher can be located. ${ }^{34}$ According to the respondents the messages in Kumasi are packaged to suit what the listening public wants to hear in order for the preacher to also milk them of their resources. ${ }^{35}$ The issue of perverted sermons was linked to the Bible by one evangelist who indicated that a major element of false preaching is in Luke 4 where Satan lifted the things of the world and its glory to Jesus. He further affirmed that unfortunately, preaching today has diverted to the path where mostly, worldly and material benefits are projected to the listeners but he believes anyone sent by God speaks the Word of God. ${ }^{36}$ Furthermore, it came up from the field study that in the Ghanaian society, the message has changed because the motive of some preachers is distorted and it has rendered the content of the message perverted. ${ }^{37}$

It was discovered through the content analysis, interviews and observations that some preachers employ abusive language and verbal attacks. One of them constantly rained abuses on people; even his technical crew covering the service were victims of his insults. Profane statements were sometimes used in his messages; whiles one thought it was a slip of the tongue, he would boldly announce that he owes no one an apology. A preacher was also observed in front of the Methodist Book Depot close to the Dr. Mensah area, Kejetia in Kumasi. While he was preaching, a shoe seller in the area expressed his hatred for that particular itinerant preacher, who often abuses people he perceives as sinners.

On the other hand, an analysis conducted on the preaching messages of preachers in Kumasi that were selected for the study revealed that four out of six preachers stayed true to scripture as the foundation for their messages. However, two of them preached without any biblical appeal, they adopted a free-style, sharing their personal opinions, which included bragging about what they can do and also advertised the sale of prophylactics throughout their preaching sessions.

\footnotetext{
31 Stott, The Message of Acts, England (Inter-Varsity Press, 1990) 82.

32 Samuel K. Adofo, The Primate, Church of the Lord Brotherhood, South-Suntreso, interview held on 21/03/2014 at 1 pm.

33 Stephen Oduro, an Evangelist who preaches around Kejetia and Neoplan Station at Asafo; the author listened to him on $12 / 07 / 2014$, at $6.30 \mathrm{am}$.

34 Daniel Yinkah-Sarfo, St. Cyprian's Anglican Church. Archbishop of the Anglican Church, 24/02/14 at 10am

35 Joseph Haleegoa, Regional Pastor, Resurrection Power and Living Bread Ministries, Santasi, interview held on 27/05/2014 at $12 \mathrm{pm}$.

36 Anthony Akwasi Kwarteng, Evangelist who hold open air crusades frequently, and Head Pastor of All Nations Resurrection Power Ministries, Kwadaso, interview held on 27/06/2014, at 4 pm.

37 Peter Osei Amoateng, Parish Priest of St. Mary's Parish, South Suntreso, interview held on 13/05/2014, at 10 am.
} 
Many respondents were concerned about the predominant lack of biblical focus in some of the messages preached in the city. Some were of the view that today's messages need a little balance. In some cases, the messages concentrate on personal development and preachers are not able to teach the people the "nitty-gritty" of the Word of God. One respondent further affirmed that certain messages lack sound biblical basics, and what makes this evident is the absence of biblical texts in their delivery. Also, the messages do not exalt Christ; they are taken out of context and virtually propagate the opinion of the preacher. ${ }^{38}$ Another respondent agreed with this view. In his opinion, preaching in Kumasi now appeals more to emotions rather than the intellect of the recipients. Preachers often give messages that generally excite hearers, to the point of satisfying their desires and make no attempt to admonish as the Bible encourages preachers to do. ${ }^{39}$

On the goal of preaching in Kumasi, diverse opinions were shared. A pastor said that the messages of repentance from sin, faith in God, faith towards God, repentance from dead works and all those foundational beliefs are not being preached in current times. ${ }^{40}$ Most churches in Kumasi have become money-making ventures instead of ministering the life-saving gospel to a dying world. ${ }^{41} \mathrm{~A}$ female preacher opined that the goal of sharing the gospel is to help people out of their problems, ensure their salvation and give them hope in Christ because so many people are fed up in Christ. ${ }^{42}$ A preacher also revealed that his objective is to see to it that every soul that belongs to Christ gets eternal life for their souls. ${ }^{43}$

However, many listeners and preachers alike in the Kumasi metropolis expressed worry about the focus of the messages being preached. According to the various views sampled, some messages do not centre on Christ. Some respondents posited that there are false preachers who are in to make money and to build fame and also seek to project themselves instead of Christ especially on billboards. ${ }^{44}$ In addition, a senior minister in the city asserted that the perverted gospel being preached in current times is often in accordance with Scripture which asserts that Jesus is the Saviour and he offers salvation to every believing soul without cost. However, the theory is also propagated by some of these pastors that one needs to provide certain material substances before he/she is saved, and this he believes is misleading and has nothing to do with the gospel. ${ }^{45}$

An evangelist supported his claim of the increasing spate of materialism in the ministry with an example of a pastor who was advised by his colleague to organize a twenty-one days revival programme to raise funds not to assist the church or the needy but to pay for a car he had purchased at a cost of Gh $\phi$ 28,000 (\$5000.00). ${ }^{46}$ This example which highlights the lack of focus of certain preachers is, unfortunately, the trend that exists in most ministries across the country. Another example is a preacher who was captured in the content analysis saying that he does not take money from people before attending to them but it was observed that upon getting to the end of his message, he mentioned that he uses fragrant oils to minister to people at a cost of Ghф 20.00 (\$4.00) per bottle, claiming it is cheaper than what others sell. To add to this, an itinerant preacher was also asked why he spent too much time appealing for funds, to which he explained that certain persons assist him to pack out his gadgets for his setup at a fee. Hence the appeal was to generate funds to pay for their services. ${ }^{47} \mathrm{In}$ light of this, he would always pass on the microphone to his assistant whose role is to appeal for funds for about an hour immediately after he finishes preaching.

38 Seidu Sumaila, Former Principal, Mid-Ghana Bible College, Assemblies of God Assemblies of God.interview held on 28/06/2014 at 4 pm.

39 Interview with Seidu Sumaila, Assemblies of God.

40 Interview with George Mensah, ICGC, Royal Temple

41 Alfred Boakye Nyamekye, General Overseer, House of Faith Ministries International, interview held on 03/07/2014, at 7am.

42 Comfort Mensah, Prophetess in charge of New Revival Holy Ghost Chapel, Nyankyerenease, interview held on 10/07/2014 at $6 \mathrm{pm}$.

43 Isaiah Asante, Branch Pastor, True Faith Church, Kwadaso-Esatate, interview held on 12/05/2014 at 11 am.

44 Adu Sekyere, Minister in Charge, Peyer Presbyterian Church, Bantama, interview held on 20/03/2014 at 11.30 am.

45 Interview with Alfred Boakye Nyamekye, House of Faith Ministries Intl.

46 Interview with Evangelist Stephen. K. Oduro.

47 Charles Akowuah, Self-Styled Evangelist who Preaches every morning at Adum, near the Traffic Light, close to UT Bank, Adum Branch, Interviewed on 09/05/2014 at $10 \mathrm{am}$. 
Nevertheless, there exist preachers of the gospel who are committed to sound biblical preaching with the aim of converting unbelievers to Christ which is the mandate of every Christian. They believe that there is a need to make people aware of the importance of repentance and turning back to Christ irrespective of whatever sins they may have committed in the past. ${ }^{48}$ In their opinion, the goal is the salvation of souls and to teach their hearers to bear spiritual fruits, and through the fruits of salvation experience healing, prosperity and other forms of blessing. ${ }^{49}$ An apostle who was interviewed stressed the concept of the four-square gospel of the Church of Pentecost as their goal for preaching as follows: first they preach Christ as Saviour with the aim of motivating members into vigorous evangelism to save lost souls. Secondly, they emphasize Christ as the baptizer because they want to encourage the reception of Holy Ghost baptism by the congregation. Thirdly, they preach Christ as the healer to ignite the expectation of members to receive miracles during church service. Lastly, they stress on Christ as the soon coming king to prepare the hearts and minds of members to be ever ready for the second advent of Christ. ${ }^{50}$

\section{The Effects of Contemporary Preaching in Kumasi}

The findings also revealed the effects of this particular form of preaching on the people of Kumasi. In some cases, the distorted messages were found to further disengage unbelievers from the Saviour of their soul and hinder their true conversion. Thus, so many people often attend church services frequently in excitement without being affected inwardly by the gospel message to live the life expected of a Christian. These distorted messages also ignite Superstition and fear among the recipients and this pushes them to buy so-called anointed items. This in turn provides the needed funds for these pastors. Also, the material focus of preachers has often led to the exploitation of the poor thereby worsening their plight. Due to the insulting nature of some of the messages, the audience (especially in market places and busy areas) often pays no heed to any message at all regardless of the preacher. To this effect, one may miss a crucial message that may lead to his/her salvation or upliftment.

Moreover, in their quest for popularity and show of power, some preachers, often resort to the proclamation of messages that endear them as the source of refuge for their hearers. It leads to dissensions in families as a result of messages which present family members and loved ones as evil-minded people waiting to devour.

\section{Theological Foundation of Christian Preaching}

The main route or path of the act of Christian preaching is to inform and the Bible should serve as the source document. The platform for Christian preaching cannot leave out a well-prepared message delivered by a well-prepared messenger whose audience encounter relevant information to walk with God. According to Howard, there are basically four essential elements in Christian preaching; the text, the congregation, the preacher, and the act of preaching. ${ }^{51}$ According to Stott, only Christian preachers are considered to be heralds of the Good News from God and tend to consider themselves as the ambassadors or representatives of God who actually utter His oracles. ${ }^{52}$ Field data indicated that contemporary preaching in Kumasi is sometimes characterized by distortions of biblical truths, use of abusive language; self-centred messages instead of Christ, and the motivation for material gains. However, it came out that there are others whose messages were biblically balanced based on sound biblical principles, and whose primary focus was to see people come to salvation through their messages just as was found in the Book of Acts. It is evident from the Book of Acts that the messages of the early Christian preachers resulted in the salvation of unbelievers and a commitment towards the Christian course.

Contemporary preaching has been battered and shattered by many difficulties and challenges travelling through the fabric of many societies. It is evident from the field data that the efforts of many

\footnotetext{
48 Charles Akowuah, Self-Styled Evangelist who Preaches every morning at Adum-Kumasi.

49 Interview with Anthony Akwasi Kwarteng, All Nations Resurrection Power Ministries, Kwadaso.

50 Ekow Badu-Wood, Kwadaso Area Head, Church of Pentecost, interview held on the 08/04/2014 at 10 am.

51 J. Grant Howard, Creativity in Preaching,(Grand Rapids: Zondervan Publishing House, 1987), 11.

52 Stott, I Believe in Preaching, 16.
} 
preachers make them go to the extent of turning the truth upside down in their quest to manipulate people to fill their auditoriums and this often raises many concerns. This to a larger extent tends to affect the salvation and spiritual growth of the audience indicating that they are just in to satisfy themselves without taking cognisance of God or the good of man. It revolves around preachers of a diverse sort, the modern society and its problems, and congregations who are not ready for what does not approve of their lifestyles. Many preachers opt for what pleases their audience and thereby preach messages that will rather attract applause.

According to an observation made by MacArthur Jr., user-friendly churches say, if you must have to deliver a sermon, keep it brief and exciting, don't be authoritative and above all keep every one of your audience entertained. ${ }^{53}$ This observation runs contrary to what Paul describes in the Word of God as rebuking and correcting (2Tim 3:16). Again, Paul warned in 1Tim 4:1-3 that a time will come when some people will not like to hear sound biblical preaching or teaching.

The resultant effects clearly indicate that many preachers in the Ghanaian society especially in Kumasi are not theologically trained and go about proclaiming perversion. In the book of Acts, one reads that, after the early believers have sat under the tutelage of the Lord, they did not divert but rather committed themselves to go the way of their master. This is not evident in some contemporary preachers who proclaim their own messages unbound by true scriptural interpretation. Although many take the call to preach very seriously, many do so for material benefits which must not be the case. Efficient study of the Word of God must be the mantra of every preacher. Hence every preacher must make a conscious effort to follow this path for successful results.

\section{Christian Preaching and the Ghanaian Society}

It is significant for Christian preaching to affect society whose members are often the audience for preachers. This is so because the people who often listen to the messages are required to make use of what they hear and which must influence their attitudes and lifestyles. Asante postulates that religion is a major player in national development and cannot be ignored. ${ }^{54}$ In the view of Stott, "the preacher is the messenger of God, and constitutes the real master of society; not elected by society to be its ruler, but elected by God to form its ideals and through them to guide and rule its life". ${ }^{55}$ Thus, it is expected that Christian preachers must deliver messages that are tailored towards reforming people and making them responsible members of the society.

It was discovered from the field study that many of the messages preached in Kumasi sometimes spark superstition and fear as well as division and conflicts in families. Again, some messages were found to promote laziness due to the theory that one can only prosper through offering prayer or relying on the use of prophylactics. With such a mentality, people often fail to work to contribute to society. This renders preaching a disincentive to the development of society.

How should Christian preaching affect society? It is significant to note that Christian preaching should inspire in people the sense of self-discipline, morality, patriotism, hard work, and charity towards one's neighbour among others. These are ingredients necessary for the holistic development of society. Therefore Christian preaching should not negatively affect society, but rather help in its building and progress.

It is significant to note that despite the preaching that often comes from the pulpits of church auditoriums, radio and television as well as from the public space by itinerant preachers, evil continues to abound with increasing intensity in Ghana. This is a major concern as far as Kumasi is concerned and this must be addressed. The actual intent of preaching must be made relevant for society in effecting changes in attitudes and lifestyles in a more positive way. According to 2Timothy 3:16, Paul admonished that the Word of God has the power to rebuke and correct situations, and should therefore be presented correctly.

As Christian believers and as a nation, each one must be alarmed that the reality has been revealed that indeed many preachers are distorting the truth. According to Payne, preaching in contemporary times

\footnotetext{
53 John F. MacArthur Jr. “Truth vs. Technique,” Quarterly Journal for Church Leadership, Volume 3, (1994): 33.

54 Emmanuel K. Asante, Issues in African Traditional Religion, Humanities, Ethnicity and Development: Impact on African Christian, Ghana (SonLife Press 2017) 60.

55 Stott, I Believe in Preaching, 17.
} 
seems to have fallen on hard times because the quality of preaching is often poor, and preaching has lost the esteem it once enjoyed. ${ }^{56}$ Due to selfish ambition, many preachers often preach anything at all, saying what has no connection with the scriptures. His observation describes today's preaching as watered-down or muddied water compared to preaching in the early years of the church in Acts. It calls for an immediate intervention to reverse this trend because the Christian church was borne out of preaching. Payne suggests that today's church needs a reformation in returning the preaching of the Word to a place of esteem and centrality which will result in the preaching of the whole counsel of God. ${ }^{57}$ Many believe reformation brought sanity to the church in the medieval period but a kind of it that will restore sound biblical teaching and preaching in the church is needed today.

Looking at the motivation of preachers who minister the word just to make ends meet and to settle on it as a profitable business, the temptation to be liberal to false teachings is very high. It leads to prosperity preaching which promises only "ice cream life" and also sets the man of God always thinking about how he can twist the gospel to acquire material wealth in abundance. Prosperity preaching, so prominent in many Neo-Pentecostal churches in West Africa, is an unbiblical ideology: which refers solely to an understanding of Christianity which takes success in business resulting in material wealth as major objectives for Christian experience because it is deemed a sign of God's blessing of an individual's faith. ${ }^{58}$ These kinds of preachers can have their way because they have succeeded to present the blessings of God as material and financial flamboyance around an individual believer. If an individual devotee lives below that description then he lives in doubt without faith and probably has missed the blessings of God for his life.

The Lord Jesus commissioned all his followers to preach with the goal of making all men his disciples on earth. The Lord employs all his disciples to use the medium of the proclamation of the gospel to turn the hearts of men to follow him and to be like him (Matt. 28:19-20). The making of people disciples of Jesus or the followers of the Lord would eventually result in producing men and women who will respond to the issues of life and that of their society as Christ. Assimeng has noted that "religion is concerned with the moral problems of individual and social action, and with the relationship of men to other men, to society as a whole, and to the world at large". ${ }^{59}$ By implication through the ministry of the true word of God many or some members of the society will make a great impact that will help narrow down evil in the Ghanaian society. Just as Jesus, and later his followers, transformed the lives of many in their time including criminals and corrupt officials including Zaccheus (Lk 19:1-10), and others, Christian preachers of today need to do the same. In the same vein, when people pervert the gospel they produce followers who are evil-minded and nation wreckers. People can be misled to think that any means by which people get rich can be considered as the blessing of God. This false view has the potential to encourage corruption in the society and also facilitate abusive attacks on the socio-economic resources of the nation.

\section{RECOMMENDATION}

Preaching in the Book of Acts made a tremendous impact on the early church. This paper has enumerated some problems of contemporary Christian preaching. In order for Christian preaching to have a theological focus, this paper recommends that ministers of the Christian gospel must be theologically trained. Again, through seminars and conferences, preachers can be abreast with how to communicate relevantly and meaningfully. This can also go a long way to curb conflicts and divisions in families caused by distorted messages. Finally, preachers must come to terms with their prophetic role, that they are the voices of God in every society and should be careful not to preach for personal gains. Preaching must result in societal transformation and therefore contemporary preachers must prioritize relating sermons that shoot down the growing ills in society and promote discipline, and patriotism in the society at large.

\footnotetext{
56 William E. Payne, "Biblical Reformation in Churches," Quarterly Journal for Church Leadership, Volume 3, (1994): 48-49.

57 Payne, "Biblical Reformation in Churches," 48-49.

58 Werner Kahl, "Prosperity-Preaching in West Africa: An Evaluation of a Contemporary Ideology from a New Testament Perspective," Ghana Bulletin of Theology, Vol. 2, (2007): 22.

59 Max Assimeng, Religion and Social Change in West Africa, Accra:Ghana (Woeli Publishing Services,2010) 12.
} 


\section{CONCLUSION}

The paper took cognisance of the nature and impact of contemporary preaching in Kumasi. The study revealed that some preachers deliver messages which are distortions of the Scriptures. Others however, considered preaching as part of their calling and were prepared to go all lengths to declare the Christian message based on sound biblical emphasis. The study therefore, contends that sound Christian preaching should be theologically balanced and focused on the spiritual growth of Christians. It should also affect society by effecting changes in attitudes and lifestyles of the people. Thus, Christian preaching should produce discipline, morality, hard work, patriotism and love for one's neighbour among others which are the ingredients for the holistic development of society.

\section{BIBLIOGRAPHY}

Asante, Emmanuel K. Issues in African Traditional Religion, Humanities, Ethnicity and Development: Impact on African Christian, (Kumasi: SonLife Press, 2017).

Assimeng, Max. Religion and Social Change in West Africa, Accra: Ghana (Woeli Publishing Services,2010) Barclays, William. The Acts of the Apostles, (Kentucky: Westminster John Knox Press,1976).

Bediako, Kwame. "Biblical Perspectives on Christian Leadership in the Ghanaian Context," Journal of African Christian Thought, vol. 17, No. 2, (2014):10-15.

Bowen, Roger eds, A Guide to Preaching, (London: SPCK, 2005).

Brand, Chad etal. Eds. Holman Illustrated Bible Dictionary, (Nashville: Holman Bible Publishers, 1998). Criswell, W. A. Acts: An Exposition, Volume I Chapters 1-8, (Michigan: Zondervan Publishing House, 1978). Gaebelein, Frank E. ed. The Expositor's Bible Commentary, (Michigan: Grand Rapids Zondervan Corporation, 1981).

Green, Michael. Acts for Today, (London: Hodder \& Stoughton, 1993).

Harrison, Everett F. Interpreting Acts: The Expanding Church, (Michigan:Grand Rapids Academic Books, 1986).

Horton, Stanley M. The Book of Acts, (Missouri: Gospel Publishing House, 1981).

Howard, J. Grant. Creativity in Preaching,(Grand Rapids: Zondervan Publishing House,1987).

Kahl, Werner. "Prosperity-Preaching in West Africa: An Evaluation of a Contemporary Ideology from a New Testament Perspective" in Ghana Bulletin of Theology, Vol. 2, (2007):21-42.

Koesler, John. The Moody Handbook of Preaching, (Chicago: Moody Publishers, 2008).

MacArthur Jr. John Rediscovering Expository Preaching, (Dallas: Word Publishing, 1992).

MacArthur Jr. John F. “Truth vs. Technique,” Quarterly Journal for Church Leadership, Volume 3 (1994):3235.

Marshall, I. Howard. The Acts of the Apostles: An Introduction and Commentary, (Michigan:Wm. B. Eerdmans Publishing Company, 1982).

Olford, Stephen F. and Olford, David L. Anointed Expository Preaching, (Nashville: B\&H Publishing Group, 1998).

Payne, William E. "Biblical Reformation in Churches," Quarterly Journal for Church Leadership, Vol 3 (1994): 47-50.

Robinson, Haddon W. Biblical Preaching, (Michigan: Baker Academic, 2001).

Stott, John R.W. I believe in Preaching, (London: Hodder and Stoughton, 1982).

Wiersbe, Warren and Wiersbe, David. The Elements of Preaching, (Illinois: Tyndale Publishing House, 1986).

Williams, David J. Acts, (Michigan: Baker Books, 1990). 


\section{ABOUT AUTHORS}

Godfred Baffour-Awuah is a Lecturer in the Department of Theology, Christian Service University College -Kumasi Ghana.

Jonathan Edward Tetteh Kuwornu-Adjaottor is an Associate Professor in New Testament and Mother Tongued Biblical Hermeneutics in the Department of Religious Studies, Kwame Nkrumah University of Science and Technology - Kumasi Ghana.

Patrick Yankyera is the Senior Pastor of the Rhema Assembly of God Church, Ahinsan Kumasi. He is currently a Phd candidate in the Department of Religious Studies, Kwame Nkrumah University of Science and Technology - Kumasi Ghana. 